\title{
Effect of Dietary Tung Oil on the Growth and Lipid Metabolism of Laying Hens
}

\author{
Jung-Suck LeE ${ }^{1,3}$, Jun-ichi TAKAI ${ }^{1}$, Kazuaki TAKAHASI ${ }^{1}$, Yasushi ENDO ${ }^{1, *}$, \\ Kenshiro Fujimoto ${ }^{1}$, Seiji KoIKE ${ }^{2}$ and Wataru Matsumoto ${ }^{2}$ \\ ${ }^{1}$ Graduate School of Agricultural Science, Tohoku University, \\ 1-1 Tsutsumidori-Amamiyamachi, Aoba, Sendai 981-8555, Japan \\ ${ }^{2}$ Asahi Denka Kogyo K.K., 7-2-35 Higashiogu, Arakawa, Tokyo 116-8553, Japan \\ ${ }^{3}$ East Coastal Marine Bioresources Research Center, 123 Jibyun-Dong, Kangnung 210-702, Korea
}

(Received October 24, 2001)

\begin{abstract}
Summary The influence of dietary tung oil, containing a high level of $\alpha$-eleostearic acid (cis-9, trans-11, trans-13-octadecatrienoic acid, EA) on growth, egg production, and lipid and fatty acid compositions in tissues and egg yolks of laying hens was studied in White Leghorn hens. Forty-week-old hens were divided into three groups of eight birds each and fed diets containing $0,0.5$, or $1.0 \%$ tung oil for $6 \mathrm{wk}$. The average body weight, feed consumption, rate of egg production, and weights of eggs and yolks were not affected. The weight of adipose tissue was remarkably small in hens fed tung oil, whereas the yolk lipid content did not change. Triglyceride level in heart and adipose tissue decreased in hens fed tung oil, and the level of linolenic acid $\left(\mathrm{C}_{18: 3}\right)$ in all tissues was decreased. $\alpha$-EA was not almost deposited in the tissues and egg yolk of hens fed tung oil, but conjugated linoleic acid (CLA) was detected in all tissues and egg yolks. The level of CLA in the tissues was significantly higher with increased dietary tung oil. The order of CLA level in tissue lipids was adipose tissue $>$ liver $>$ heart $>$ breast muscle. Especially, the level of CLA in the lipids of adipose tissue and egg yolks of hens fed $1.0 \%$ tung oil was $2.0 \%$ of the total fatty acid. These results supposed that dietary tung oil affected the lipid metabolism of laying hens and could modify the lipid and fatty acid composition in tissues and eggs.
\end{abstract}

Key Words conjugated fatty acid, eleostearic acid, hens, lipid metabolism, tung oil

Although natural polyunsaturated fatty acids were generally nonconjugated, many varieties of conjugated fatty acids are present as minor fatty acids in plants and animals. Conjugated linoleic acid (CLA), a mixture of positional and geometrical isomers of linoleic acid (cis9, cis-12-octadecadienoic acid), which is contained as minor lipids in dairy products such as beef, cheese, and milk, has been known to have specifically physiological effects, including the reduction of body weight gain and fat deposition (1-3), anticarcinogenesis (4-7), and antiatherosclerosis $(8,9)$.

Based on these studies concerning CLA, it could be hypothesized that the conjugated fatty acids besides CLA would also have various biological activities. This hypothesis is supported by several observations. Igarashi and Miyazawa (10) reported that conjugated octadecatrienoic fatty acids, including $\alpha$-eleostearic acid (cis-9, trans-11, trans-13-octadecatrienoic acid; $\alpha$ EA) were more cytotoxic to human tumor cells than CLA was. Dhar et al. (11) showed that $0.5 \% \alpha$-EA in the diet had an antioxidant effect to lower the lipid peroxidation in the livers of rats.

Reiser (12) and Mead et al. (13) have investigated the metabolism of dietary $\alpha$-EA in rats, and they reported

* To whom correspondence should be addressed.

E-mail: endo@biochem.tohoku.ac.jp that $\alpha$-EA could be rapidly converted into conjugated octadecadienoic acid in the animal body. However, these data were obtained only through ultraviolet spectrophotometry, and the accuracy content and the structure of conjugated octadecadienoic acid were not clarified. Moreover, there is no information about the effects of $\alpha$-EA on the growth and lipid metabolism of hens in vivo, although the effect of dietary CLA has been investigated (14-16).

Tung oil, which has been used in the paint and varnish industries for many years, contains $70 \%$ to $80 \%$ eleostearic acid (9,11,13-octadecatrienoic acid; EA) of total fatty acids. It could be expected to be a resource of the functional conjugated fatty acids in animal feed because of its relatively low price and its higher EA content than other EA-rich oils, such as karela oil $(17,18)$.

In this paper, we have investigated the dietary effects of EA-rich tung oil on growth performance, egg production, and tissue lipids of laying hens. Also we investigated metabolism of dietary EA in hens to apply tung oil to functional feeds for hens and chickens.

\section{EXPERIMENTAL}

Diets. Basal diets as shown in Table 1 were purchased from Kyodo Shiryo Co. Ltd. (Ibaraki, Japan).

Refined tung oil, which contained 60\% $\alpha$-EA (cis-9, trans-11, trans-13-octadecatrienoic acid) and 10\% $\beta$ - 
EA (trans-9, trans-11, trans-13-octadecatrienoic acid) was provided by Asahi Denka Kogyo K.K. (Tokyo, Japan). Refined soybean oil was provided by Ajinomoto Co. (Tokyo, Japan). The composition of the diets and the fatty acid composition of the total lipids $(6.2 \%)$ of the experimental diets are presented in Tables 1 and 2, respectively.

Hen feeding and sample preparation. Forty-week-old White Leghorn hens were obtained from Iwatani Poultry Farm (Sendai, Japan). They were kept in individual cages, divided into three groups of eight birds each, and fed corn-soybean meal based experimental diets containing 3.75\% soybean oil (Control), 3.25\% soybean oil $+0.5 \%$ tung oil $(0.5 \%$ TO), or $2.75 \%$ soybean oil $+1.0 \%$ tung oil $(1.0 \%$ TO) as oils for $6 \mathrm{wk}$. $\alpha$ Tocopherol was added to all oils to prevent oxidation during the experiment at the level of $0.1 \%$. Diets and water were provided for ad libitum consumption through the experiment.

Body weights were recorded at the start and the end of the 6 -wk trial. Feed consumption and egg production data were recorded daily for $4 \mathrm{wk}$. Blood was collected under the wing after $4 \mathrm{wk}$. At the end of the experimental period, all hens were weighed and killed by decapitation, and tissue samples (liver, heart, adipose tissue, and breast muscle) were collected and stored at $-80^{\circ} \mathrm{C}$ until analyzed.

Lipid extraction and analysis. The total lipids were extracted from tissue samples and diets by the method of Folch et al. (19). The lipid class in the tissues was separated by thin-layer chromatography on silica gel chromatorods by the use of $n$-hexane/diethyl ether/acetic acid $(80: 20: 1$, by vol.) as developing solvents, and quantified by IATROSCAN (TH-10 TLC/FID analyzer, Tokyo, Japan). Cholesterol was determined by the gasliquid chromatographic method (20). Fatty acid methyl esters of the total lipids were prepared by the use of acidcatalyzed methanolysis, as previously described (21). Fatty acid methyl esters were separated and quantified by gas chromatography with a CP-Sil 88 fused silica capillary column $(50 \mathrm{~m} \times 0.25 \mathrm{~mm}, 0.25 \mu \mathrm{m}$ film thickness, Chrompack). The initial column temperature was set at $170^{\circ} \mathrm{C}$ and increased to $225^{\circ} \mathrm{C}$ at $4^{\circ} \mathrm{C} / \mathrm{min}$. The injector and detector were set at $250^{\circ} \mathrm{C}$.

Triglyceride, phospholipid, and total cholesterol in plasma were measured by the enzymatic method, with the use of a commercial assay kit.

Statistical analysis. Data were analyzed and a oneway analysis of variance followed by Tukey's test and were represented as averages and means of standard errors.

\section{RESULTS AND DISCUSSION}

Growth performance and egg production

Initial and final body weights, feed consumption, and rate of egg production are shown in Table 3. There was no significant difference in the average weight and feed consumption of all groups, though the slight loss of body weight gain was observed in the $1.0 \%$ TO group. All hens had a high rate of egg production (87-89\%).
Table 1. The ingredients and nutrient composition of diets containing different concentrations of tung oil (TO) fed to laying hens.

\begin{tabular}{lccc}
\hline & \multicolumn{3}{c}{ Diet } \\
\cline { 2 - 4 } Ingredients ${ }^{1}$ and analysis & Control & $0.5 \%$ TO & $1.0 \%$ TO \\
\hline Corn & 56.5 & 56.5 & 56.5 \\
Soybean meal & 20.8 & 20.8 & 20.8 \\
Rape meal & 2.96 & 2.96 & 2.96 \\
Corn gluten meal & 4.64 & 4.64 & 4.64 \\
Soybean oil & 3.75 & 3.25 & 2.75 \\
Tung oil & 0.00 & 0.50 & 1.00 \\
Calcium carbonate & 8.27 & 8.27 & 8.27 \\
Dicalcium phosphate & 1.65 & 1.65 & 1.65 \\
Sodium chloride & 0.34 & 0.34 & 0.34 \\
DL-Methionine & 0.98 & 0.98 & 0.98 \\
L-Lysine $\cdot$ HCl & 0.01 & 0.01 & 0.01 \\
Vitamin $\cdot$ mineral premix ${ }^{2}$ & 0.06 & 0.06 & 0.06 \\
Choline chloride $(50 \%)$ & 0.04 & 0.04 & 0.04 \\
Calculated analysis & \multicolumn{3}{c}{} \\
Metabolizable energy, kcal/kg & 2,870 & 2,870 & 2,870 \\
Crude protein, \% & 18.1 & 18.1 & 18.1 \\
Calcium, \% & 3.78 & 3.78 & 3.78 \\
Phosphorus, \% & 0.66 & 0.66 & 0.66 \\
Available phosphorus, \% & 0.42 & 0.42 & 0.42 \\
Sodium, \% & 0.15 & 0.15 & 0.15 \\
Lysine, \% & 0.86 & 0.86 & 0.86 \\
Methionine, \% & 0.42 & 0.42 & 0.42 \\
& \multicolumn{3}{c}{}
\end{tabular}

${ }^{1}$ The composition of each ingredient is the percentage of diet.

${ }^{2}$ Calculated vitamin and mineral content of diets provided (per $\mathrm{kg}$ diet): vitamin $\mathrm{A}, 12,000 \mathrm{IU}$; vitamin $\mathrm{D}_{3}$, 3,000 IU; vitamin E, $40 \mathrm{IU}$; vitamin $\mathrm{K}, 2 \mathrm{mg}$; pantothenic acid, $14 \mathrm{mg}$; riboflavin, $6.5 \mathrm{mg}$; folic acid, $1 \mathrm{mg}$; niacin, $40 \mathrm{mg}$; thiamine, $3.5 \mathrm{mg}$; pyridine, $12 \mathrm{mg}$; biotin, $0.2 \mathrm{mg}$; vitamin $\mathrm{B}_{12}, 0.02 \mathrm{mg}$; iodine, $0.5 \mathrm{mg}$; manganese, $75 \mathrm{mg}$; copper, $15 \mathrm{mg}$; zinc, $80 \mathrm{mg}$; selenium, $0.5 \mathrm{mg}$; iron, $100 \mathrm{mg}$.

Table 2. Major fatty acid composition of tung oil (TO) and experimental diets.

\begin{tabular}{crrrr}
\hline & & \multicolumn{3}{c}{ Diet } \\
\cline { 3 - 5 } Fatty acid $^{1}$ & TO & & \\
\cline { 3 - 5 } & & Control & $0.5 \%$ TO & $1.0 \%$ TO \\
\hline Palmitic acid $\left(\mathrm{C}_{16: 0}\right)$ & 3.4 & 11.5 & 10.8 & 9.9 \\
Stearic acid $\left(\mathrm{C}_{18: 0}\right)$ & 3.2 & 3.9 & 3.7 & 3.4 \\
Oleic acid $\left(\mathrm{C}_{18: 1}\right)$ & 7.1 & 25.7 & 24.3 & 22.5 \\
Linoleic acid $\left(\mathrm{C}_{18: 2}\right)$ & 11.1 & 52.0 & 47.1 & 45.0 \\
Linolenic acid $\left(\mathrm{C}_{18: 3}\right)$ & 0.3 & 5.3 & 4.9 & 4.6 \\
$\alpha$-Eleostearic acid & 59.8 & 0.0 & 3.5 & 6.8 \\
$\left(\mathrm{C}_{18: 3} \Delta 9 \mathrm{c}, 11 \mathrm{t}, 13 \mathrm{t}\right)$ & & & & \\
$\beta$-Eleostearic acid & 10.5 & 0.0 & 2.0 & 3.4 \\
$\left(\mathrm{C}_{18: 3} \Delta 9 \mathrm{t}, 11 \mathrm{t}, 13 \mathrm{t}\right)$ & & & & \\
\hline
\end{tabular}

${ }^{1}$ Values are weight percentage of total fatty acids.

Dietary tung oil gave no nonnutritional effect to hens

As shown in Table 3, the weights of egg and yolk were $68 \mathrm{~g}$ and $19 \mathrm{~g}$ for all groups, respectively. The con- 
Table 3. Influence of dietary tung oil (TO) on the growth performance of laying hens.

\begin{tabular}{lcccc}
\hline & \multicolumn{3}{c}{ Dietary group } & Pooled SE \\
\cline { 2 - 3 } & Control & $0.5 \% \mathrm{TO}$ & $1.0 \% \mathrm{TO}$ & 0.034 \\
\hline Initial body weight $(\mathrm{kg})^{1}$ & 1.67 & 1.66 & 1.63 & 0.028 \\
Final body weight $(\mathrm{kg})^{1}$ & 1.72 & 1.65 & 1.61 & 4.96 \\
Feed consumption $(\mathrm{g} / \mathrm{hen} / \mathrm{d})^{1}$ & 120 & 121 & 123 & 1.69 \\
Rate of egg production $(\%)^{1,2}$ & 89.4 & 88.0 & 86.6 & 1.12 \\
Egg weight $(\mathrm{g})^{1,2}$ & 68.0 & 67.9 & 67.4 & 0.266 \\
Yolk weight $(\mathrm{g})^{1,2}$ & 18.9 & 18.7 & 19.0 & 0.007 \\
Egg lipid $(\mathrm{g} / \mathrm{g} \text { yolk })^{1,2}$ & 0.28 & 0.28 & 0.27 & \\
\hline
\end{tabular}

${ }^{1}$ Values are means of 8 hens or 5 to 8 eggs per dietary treatment.

${ }^{2}$ Values are cumulative data for $4 \mathrm{wk}$.

Table 4. Influence of dietary tung oil (TO) on weight and fat content of tissues in laying hens.

\begin{tabular}{|c|c|c|c|c|}
\hline & \multicolumn{3}{|c|}{ Dietary group } & \multirow{2}{*}{ Pooled SE } \\
\hline & Control & $0.5 \% \mathrm{TO}$ & $1.0 \%$ TO & \\
\hline \multicolumn{5}{|l|}{ Weight ${ }^{1,2}$} \\
\hline Liver & 2.30 & 2.50 & 2.44 & 0.072 \\
\hline Heart & 0.41 & 0.40 & 0.38 & 0.013 \\
\hline Adipose tissue & $2.71^{\mathrm{a}}$ & $1.76^{\mathrm{b}}$ & $1.95^{\mathrm{ab}}$ & 0.327 \\
\hline \multicolumn{5}{|l|}{ Fat content $(\%)^{2}$} \\
\hline Liver & 9.31 & 9.73 & 9.55 & 0.604 \\
\hline Heart & 9.39 & 9.26 & 9.40 & 0.575 \\
\hline Adipose tissue & 90.4 & 88.2 & 88.8 & 1.44 \\
\hline Breast muscle & 1.40 & 1.37 & 1.51 & 0.117 \\
\hline
\end{tabular}

${ }^{1}$ Tissue weights are represented as $(\mathrm{g} / \mathrm{g}$ body weight $) \times 100$.

${ }^{2}$ Values are means of 8 hens per dietary treatment.

Values in rows with different letters are significantly different $(p<0.05)$.

Table 5. Influence of dietary tung oil (TO) on lipid class of tissues in laying hens.

\begin{tabular}{|c|c|c|c|c|}
\hline & \multicolumn{3}{|c|}{ Dietary group } & \multirow{2}{*}{ Pooled SE } \\
\hline & Control & $0.5 \% \mathrm{TO}$ & $1.0 \% \mathrm{TO}$ & \\
\hline \multicolumn{5}{|l|}{ Liver $(\mathrm{g} / 100 \mathrm{~g})^{1}$} \\
\hline Triglyceride & 4.70 & 5.17 & 4.97 & 0.249 \\
\hline Cholesterol & 0.252 & 0.244 & 0.248 & 0.034 \\
\hline Phospholipid & 4.16 & 4.24 & 4.25 & 0.229 \\
\hline \multicolumn{5}{|l|}{ Heart $(\mathrm{g} / 100 \mathrm{~g})^{1}$} \\
\hline Triglyceride & $6.13^{\mathrm{a}}$ & $5.52^{\mathrm{ab}}$ & $5.29^{\mathrm{b}}$ & 0.146 \\
\hline Cholesterol & 0.134 & 0.136 & 0.142 & 0.012 \\
\hline Phospholipid & $2.93^{\mathrm{a}}$ & $3.43^{\mathrm{ab}}$ & $3.78^{\mathrm{b}}$ & 0.148 \\
\hline \multicolumn{5}{|c|}{ Adipose tissue $(\mathrm{g} / 100 \mathrm{~g})^{1}$} \\
\hline Triglyceride & $86.9^{\mathrm{a}}$ & $83.5^{\mathrm{a}}$ & $78.8^{\mathrm{b}}$ & 0.970 \\
\hline Cholesterol & $0.443^{\mathrm{a}}$ & $0.767^{\mathrm{a}}$ & $1.32^{\mathrm{b}}$ & 0.162 \\
\hline Phospholipid & $1.47^{\mathrm{a}}$ & $2.20^{\mathrm{a}}$ & $4.30^{b}$ & 0.463 \\
\hline \multicolumn{5}{|c|}{ Breast muscle $(g / 100 g)^{1}$} \\
\hline Triglyceride & 0.433 & 0.428 & 0.529 & 0.040 \\
\hline Cholesterol & 0.042 & 0.035 & 0.040 & 0.004 \\
\hline Phospholipid & 0.904 & 0.877 & 0.919 & 0.040 \\
\hline
\end{tabular}

\footnotetext{
${ }^{1}$ Values are means of 8 hens per dietary treatment.
}

Values in rows with different letters are significantly different $(p<0.05)$. 
Table 6. Influence of dietary tung oil on the lipid composition in plasma of laying hens.

\begin{tabular}{lcccc}
\hline & \multicolumn{3}{c}{ Dietary group } & \\
\cline { 2 - 4 } Lipids $(\mathrm{mg} / 100 \mathrm{~mL})^{1}$ & \multicolumn{3}{c}{ Pooled SE } \\
\cline { 2 - 5 } & Control & $0.5 \%$ TO & $1.0 \%$ TO & \\
\hline Triglyceride & 124 & 108 & 129 & 17.0 \\
Cholesterol & $107^{\mathrm{a}}$ & $73.8^{\mathrm{b}}$ & $91.1^{\mathrm{ab}}$ & 7.73 \\
Phospholipid & 51.7 & 43.9 & 48.3 & 4.64 \\
\hline
\end{tabular}

${ }^{1}$ Values are means of 8 hens per dietary treatment. Values in rows with different letters are significantly different $(p<0.05)$.

tent of yolk lipid was also the same for all groups (27-28\%). Dietary tung oil did not apparently affect the egg. Jones et al. (14) have investigated the effects of CLA on the growth performance and eggs of laying hens. They reported that dietary CLA did not affect the weights of egg and yolk or egg production, but that a high dose of CLA decreased the body weight. On the other hand, it was reported that average body weight and the weights of egg and yolk were decreased for hens fed 5.0\% CLA (15). When Dhar and Bhattacharyya (22) gave karela oil consisting of $50 \%$ EA to rats for $6 \mathrm{wk}$ at a concentration of $20 \%$, a slight difference was noted in the growth pattern and food efficiency between the karela oil and the linseed oil groups. Our result was similar to that of Jones et al. Dietary EA did not affect the growth performance and egg production of hens at a concentration of $1.0 \%$.

Weight and lipid content of tissues

The weight and lipid content of major tissues (liver, heart, breast muscle, and adipose tissue) were shown in Table 4 . The weight of adipose tissue was smaller in the $0.5 \%$ and $1.0 \%$ TO groups, though no significant differences were found in the weights of the livers and hearts of all groups.

No significant difference occurred in the lipid content of all tissues, as shown in Table 4. Dietary tung oil did not affect the lipid level in the hen tissues.

Lipid and fatty acid composition of tissues and blood

The lipid compositions of major tissues and plasma were shown in Tables 5 and 6 . No significant difference was observed in the lipid composition of the livers and breast muscles of all groups. On the other hand, the triglyceride level in heart and adipose tissue was lower in the hens fed tung oil. Especially, the heart and adipose tissue of the $1.0 \%$ TO group contained the least amount of triglyceride. On the other hand, the levels of phospholipid and cholesterol were increased in the adipose tissue of hens fed tung oil. Dhar and Bhattacharyya (22) reported that dietary EA-rich karela oil increased the total cholesterol and triglyceride in the plasma of rats. However, cholesterol was decreased in the plasma of hens fed tung oil (Table 6). The lipid modulation-effect of EA may depend on the species of animals.

The fatty acid compositions of lipids in major tissues and plasma are shown in Tables 7 and 8. Major fatty acids were palmitic $\left(\mathrm{C}_{16: 0}\right)$, stearic $\left(\mathrm{C}_{18: 0}\right)$, oleic $\left(\mathrm{C}_{18: 1}\right)$,

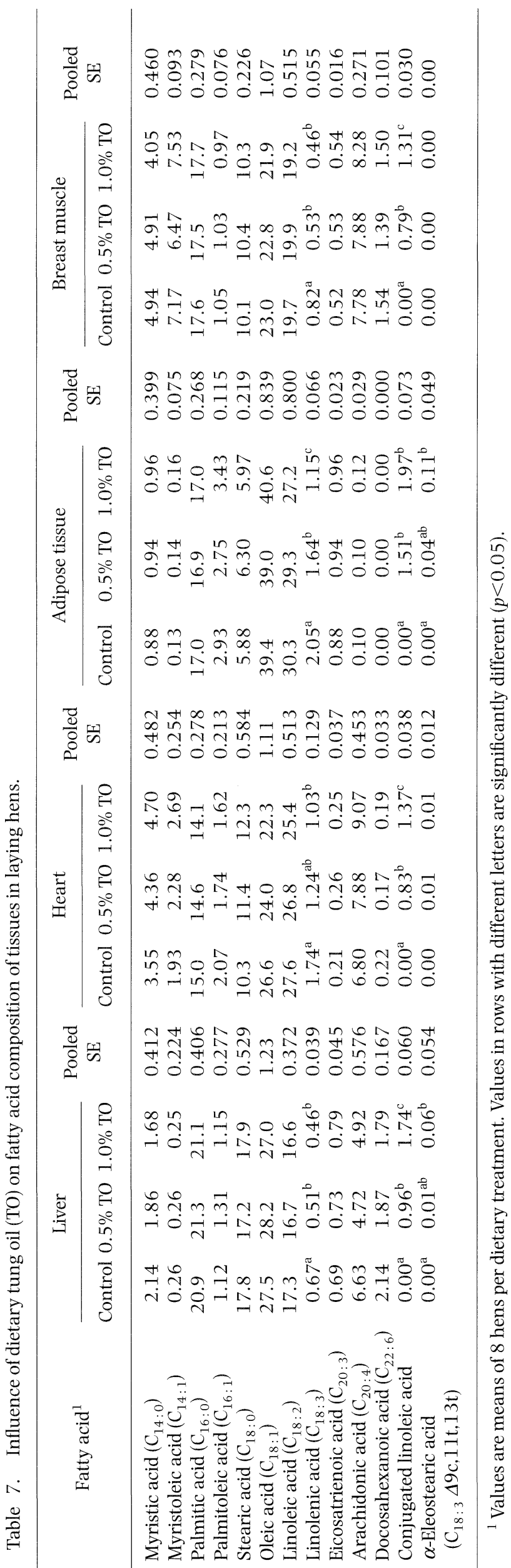


Table 8. Influence of dietary tung oil (TO) on fatty acid composition of plasma in laying hens.

\begin{tabular}{|c|c|c|c|c|}
\hline \multirow{2}{*}{ Fatty acid ${ }^{1}$} & \multicolumn{3}{|c|}{ Dietary group } & \multirow{2}{*}{ Pooled SE } \\
\hline & Control & $0.5 \% \mathrm{TO}$ & $1.0 \% \mathrm{TO}$ & \\
\hline Myristic acid $\left(\mathrm{C}_{14: 0}\right)$ & 0.67 & 1.31 & 2.38 & 0.460 \\
\hline Myristoleic acid $\left(\mathrm{C}_{14: 1}\right)$ & 0.37 & 0.33 & 0.54 & 0.170 \\
\hline Palmitic acid $\left(\mathrm{C}_{16: 0}\right)$ & 19.3 & 19.4 & 18.0 & 0.372 \\
\hline Palmitoleic acid $\left(\mathrm{C}_{16: 1}\right)$ & 1.83 & 2.00 & 1.54 & 0.158 \\
\hline Stearic acid $\left(\mathrm{C}_{18: 0}\right)$ & 7.66 & 7.84 & 6.92 & 0.369 \\
\hline Oleic acid $\left(\mathrm{C}_{18: 1}\right)$ & 37.6 & 35.9 & 30.6 & 1.09 \\
\hline Linoleic acid $\left(\mathrm{C}_{18: 2}\right)$ & 23.8 & 21.1 & 19.9 & 0.693 \\
\hline Linolenic acid $\left(\mathrm{C}_{18: 3}\right)$ & 1.99 & 1.59 & 2.10 & 0.105 \\
\hline Eicosatrienoic acid $\left(\mathrm{C}_{20: 3}\right)$ & 0.48 & 0.39 & 0.26 & 0.039 \\
\hline Arachidonic acid $\left(\mathrm{C}_{20: 4}\right)$ & 1.23 & 0.85 & 0.81 & 0.104 \\
\hline Docosahexanoic acid $\left(\mathrm{C}_{22: 6}\right)$ & $0.79^{\mathrm{a}}$ & $0.36^{\mathrm{ab}}$ & $0.22^{b}$ & 0.083 \\
\hline Conjugated linoleic acid & $0.00^{\mathrm{a}}$ & $1.53^{\mathrm{b}}$ & $3.14^{\mathrm{c}}$ & 0.062 \\
\hline $\begin{array}{l}\alpha \text {-Eleostearic acid } \\
\left(\mathrm{C}_{18 \cdot 3} \Delta 9 \mathrm{c}, 11 \mathrm{t}, 13 \mathrm{t}\right)\end{array}$ & 0.00 & 0.16 & 0.11 & 0.031 \\
\hline
\end{tabular}

${ }^{1}$ Values are means of 8 hens per dietary treatment.

Values in rows with different letters are significantly different $(p<0.05)$.

and linoleic $\left(\mathrm{C}_{18: 2}\right)$, regardless of tissue varieties. The linolenic acid $\left(\mathrm{C}_{18: 3}\right)$ level in all tissues of the $0.5 \%$ and $1.0 \%$ TO groups was lower than that in the control group. The $\mathrm{C}_{18: 3}$ level was lower with increased dietary tung oil. Moreover, the decrease in the docosahexaenoic acid $\left(\mathrm{C}_{22: 6}\right)$ level was observed in the plasma of hens fed tung oil (Table 8). Chamruspollert and Sell (16) observed the decreased $\mathrm{C}_{18: 2}, \mathrm{C}_{18: 3}, \mathrm{C}_{20: 4}$, and $\mathrm{C}_{22: 6}$ in plasma and the decreased $\mathrm{C}_{18: 3}$ in the body fat of hens fed $5.0 \%$ CLA. Our observation was similar to theirs. Dietary EA-rich tung oil could modify the fatty acid composition in the tissues of hens, and its effect was similar to that of CLA.

EA was nearly undetected in all tissues of all groups, though large amounts of EA as tung oil were given to hens. Trace amounts of $\alpha$-EA (below $0.1 \%$ ) were detected only in liver and adipose tissue of the $1.0 \%$ TO group, but CLA was detected in all tissues of hens fed tung oil. The level of CLA in tissues was higher with increased dietary tung oil. The order of CLA level in tissue lipids was adipose tissue $>$ liver $>$ heart $>$ breast muscle. Especially, the CLA level in adipose tissue of the $1.0 \%$ TO group was $2.0 \%$ of total fatty acids. We tried to identify the CLA by the silver ion-high-performance liquid chromatography. The result revealed that CLA detected in adipose tissue was a mixture of cis-9, trans-11-octadecadienoic acid and trans-9, trans-11-octadecadienoic acid (data not shown).

As shown in Table 8, trace amounts of $\alpha$-EA $(0.1-$ $0.2 \%$ ) were detected in the plasma of the $0.5 \%$ and $1.0 \%$ TO groups, whereas the level of CLA was 1.5$3.1 \%$. This observation was similar to what was found in tissues. Dietary $\alpha$-EA was scarcely deposited in plasma lipids; its part was converted to CLA.

We also investigated lipid contained in the feces of hens fed tung oil and found nearly no dietary lipids, including tung oil, remaining. From these results, most
Table 9. Influence of dietary tung oil (TO) on lipid class of egg yolk.

\begin{tabular}{lcccc}
\hline & \multicolumn{3}{c}{ Dietary group } & Pooled \\
\cline { 2 - 4 } Lipids $(\mathrm{g} / 100 \mathrm{~g})^{1}$ & Control & $0.5 \% \mathrm{TO}$ & $1.0 \% \mathrm{TO}$ & $\mathrm{SE}$ \\
\cline { 2 - 4 } & & & & \\
\hline Triglyceride & 15.6 & 15.7 & 16.6 & 0.295 \\
Cholesterol & 0.784 & 0.937 & 0.851 & 0.070 \\
Phospholipid & 11.2 & 10.5 & 10.3 & 0.296 \\
\hline
\end{tabular}

${ }^{1}$ Values are means of 5 to 7 eggs per dietary treatment. Egg yolk was obtained after a 4-wk breeding.

EA might be quickly $\beta$-oxidized and consumed as an energy after absorption, whereas some dietary EA was converted to CLA by the hydrogenation of a double bond at position 13. Thus dietary EA was almost not deposited in hen tissues.

Sakono et al. (23) reported that dietary CLA could enhance $\beta$-oxidation in rat liver. Belury et al. (24) found the induction of mRNA of hepatic acyl-CoA oxidase in mouse by dietary CLA. Probably, EA might also enhance the activity and mRNA of hepatic enzymes in $\beta$ oxidation. As a result, EA might be susceptible to $\beta$-oxidation. Unfortunately, the mechanism of the hydrogenation of EA to CLA is unknown in hens, though rumen microorganisms could produce CLA from linolenic and linoleic acids (25).

Lipid and fatty acid composition of egg yolk

The levels of triglyceride, cholesterol, and phospholipid in egg yolk did not change after a 4-wk breeding supplemented with tung oil, as shown in Table 9. Dietary tung oil did not remarkably affect the lipid composition of egg yolk. Table 10 shows the fatty acid composition in egg yolk from hens fed tung oil for 1 and $4 \mathrm{wk}$. The major fatty acids in egg yolk lipid were $\mathrm{C}_{18: 1}$, $\mathrm{C}_{16: 0}, \mathrm{C}_{18: 2}$, and $\mathrm{C}_{18: 0}$, and they did not change during 
Table 10. Influence of dietary tung oil (TO) on fatty acid composition in egg yolk lipid.

\begin{tabular}{|c|c|c|c|c|c|c|c|}
\hline \multirow{2}{*}{ Fatty acid ${ }^{1}$} & \multicolumn{3}{|c|}{$1 \mathrm{wk}$} & \multicolumn{3}{|c|}{$4 \mathrm{wk}$} & \multirow{2}{*}{ Pooled SE } \\
\hline & Control & $0.5 \% \mathrm{TO}$ & $1.0 \% \mathrm{TO}$ & Control & $0.5 \% \mathrm{TO}$ & $1.0 \% \mathrm{TO}$ & \\
\hline Myristic acid $\left(\mathrm{C}_{14: 0}\right)$ & 1.46 & 0.81 & 0.79 & 0.32 & 0.35 & 0.33 & 0.195 \\
\hline Myristoleic acid $\left(\mathrm{C}_{14: 1}\right)$ & 0.08 & 0.17 & 0.16 & 0.10 & 0.16 & 0.11 & 0.038 \\
\hline Palmitic acid $\left(\mathrm{C}_{16: 0}\right)$ & 24.3 & 25.4 & 25.2 & 24.2 & 24.4 & 24.7 & 0.351 \\
\hline Stearic acid $\left(\mathrm{C}_{18: 0}\right)$ & 13.8 & 12.6 & 12.3 & 14.2 & 14.4 & 14.8 & 1.15 \\
\hline Oleic acid $\left(C_{18: 1}\right)$ & 33.8 & 33.9 & 34.5 & 34.7 & 33.8 & 32.4 & 1.06 \\
\hline Linoleic acid $\left(\mathrm{C}_{18: 2}\right)$ & 17.0 & 17.3 & 16.8 & 17.4 & 17.2 & 16.9 & 0.457 \\
\hline Linolenic acid $\left(\mathrm{C}_{18: 3}\right)$ & 0.53 & 0.38 & 0.36 & 0.60 & 0.63 & 0.63 & 0.062 \\
\hline Eicosatrienoic acid $\left(\mathrm{C}_{20: 3}\right)$ & 0.22 & 0.31 & 0.30 & 0.27 & 0.36 & 0.38 & 0.040 \\
\hline Arachidonic acid $\left(\mathrm{C}_{20: 4}\right)$ & 3.50 & 3.27 & 2.82 & 3.20 & 2.96 & 2.96 & 0.347 \\
\hline Docosahexanoic acid $\left(\mathrm{C}_{22: 6}\right)$ & 1.60 & 1.53 & 1.18 & 1.57 & 1.35 & 1.24 & 0.103 \\
\hline Conjugated linoleic acid & $0.00^{\mathrm{a}}$ & $0.94^{\mathrm{b}}$ & $1.94^{\mathrm{c}}$ & $0.00^{\mathrm{a}}$ & $1.12^{b}$ & $2.38^{\mathrm{c}}$ & 0.051 \\
\hline $\begin{array}{l}\alpha \text {-Eleostearic acid } \\
\left(\mathrm{C}_{18: 3} \Delta 9 \mathrm{c}, 11 \mathrm{t}, 13 \mathrm{t}\right)\end{array}$ & 0.00 & 0.00 & 0.00 & 0.00 & 0.00 & 0.00 & 0.00 \\
\hline
\end{tabular}

${ }^{1}$ Values are means of 5 to 7 eggs per dietary treatment. Values in rows with different letters are significantly different $(p<0.05)$.

breeding. There was no significant difference in the level of other fatty acids in egg yolk from all groups, though DHA decreased in egg yolk from hens fed tung oil. EA derived from dietary tung oil was not detected in egg yolk lipid, whereas CLA was detected in egg yolk from hens fed tung oil. Especially, the CLA level was higher in egg yolk from the $1.0 \%$ TO group. This result was similar to that obtained in tissues, as shown in Table 7. Moreover, the CLA level in egg yolk from the $1.0 \%$ TO group after a 4 -wk breeding was $2.4 \%$, and it was higher than that after a 1 -wk breeding (1.9\%). These observations showed that dietary EA was not directly transferred in egg yolk lipid and that its part was deposited after conversion to CLA.

In this study, we investigated the influence of dietary EA on the growth performance and lipid metabolism of hens. When EA-rich tung oil was given to laying hens, the growth and egg production of hens were not affected. However, the weight of adipose tissue was decreased by dietary tung oil. Moreover, the lipid and fatty acid composition of tissues in hens could be modified by dietary tung oil.

Unfortunately, dietary EA was not deposited in the eggs and tissues of hens, but dietary tung oil induced the accumulation of CLA in the tissues and egg yolks of hens. These observations suppose that a utilization of tung oil to feed may be also effective for the supplementation of CLA in chicken.

\section{Acknowledgments}

This work was supported in part by a grant-in-aid for JSPS postdoctoral fellowships for foreign researchers in Japan.

\section{REFERENCES}

1) Chin SF, Storkson JM, Albright KJ, Cook ME, Pariza MW. 1994. Conjugated linoleic acid is a growth factor for rats as shown by enhanced weight gain and improved feed efficiency. J Nutr 124: 2344-2349.

2) Belury MA, Kempa-Steczko A. 1997. Conjugated linoleic acid modulates hepatic lipid composition. Lipids 32: 199-204.

3) Park Y, Albright KJ, Liu W, Storkson JM, Cook ME, Pariza MW. 1997. Effect of conjugated linoleic acid on body composition in mice. Lipids 32: 853-858.

4) Ha YS, Storkson J, Pariza MW. 1990. Inhibition of benzo[a]pyrene-induced mouse forestomach neoplasia by conjugated dienoic derivatives of linoleic acid. Cancer Res 50: 1097-1101.

5) Shultz TD, Chew BP, Seaman WR, Luedecke LO. 1992. Inhibitory effect of conjugated dienoic derivatives of linoleic acid $\beta$-carotene on the in vitro growth of human cancer cells. Cancer Lett 63: 125-133.

6) Ip C, Singh M, Thompson HJ, Scimeca JA. 1994. Conjugated linoleic acid suppresses mammary carcinogenesis and proliferative activity of the mammary gland in the rat. Cancer Res 54: 1212-1215.

7) Wong MW, Chew BP, Wong TS, Hosick HL, Boylston TD, Shultz TD. 1997. Effects of dietary conjugated linoleic acid on lymphocyte function and growth of mammary tumors in mice. Anticancer Res 17: $987-$ 994.

8) Lee KN, Kritchevsky D, Pariza MW. 1994. Conjugated linoleic acid and atherosclerosis in rabbit. Atherosclerosis 108: 19-25.

9) Nicolosi RJ, Rogers EJ, Kritchevsky D, Scimeca JA, Huth PJ. 1997. Dietary conjugated linoleic acid reduces plasma lipoproteins and early aortic atherosclerosis in hypercholesterolemic hamsters. Artery 22: 266-277.

10) Igarashi M, Miyazawa T. 2000. Newly recognized cytotoxin effect of conjugated trienoic fatty acids on cultured human tumor cells. Cancer Lett 148: 173-179.

11) Dhar P, Ghosh S, Bhattacharyya DK. 1999. Dietary effects of conjugated octadecatrienoic fatty acid $(9 \mathrm{cis}$, 11 trans, 13trans) levels on blood lipids and nonenzymatic in vitro lipid peroxidation in rats. Lipids $\mathbf{3 4}$ : 109-114.

12) Reiser R. 1951. The biochemical conversions of conjugated dienoic and trienoic fatty acids. Arch Biochem 32: 
113-120.

13) Mead JF, Fillerup DL, Decker AB, Bennett LR. 1951. The measurement of fat absorption and distribution using eleostearic acid. J Biol Chem 189: 499-513.

14) Jones S, Ma DWL, Robinson FE, Field CJ, Clandinin MT. 2000. Isomers of conjugated linoleic acid (CLA) are incorporated into egg yolk lipids by CLA-fed laying hens. J Nutr 130: 2002-2005.

15) Ahn DU, Sell JL, Jo C, Chamruspollert M, Jeffrey $M$. 1999. Effect of dietary conjugated linoleic acid on the quality characteristics of chicken eggs during refrigerated storage. Poultry Sci 78: 922-928.

16) Chamruspollert M, Sell JL. 1999. Transfer of dietary conjugated linoleic acid to egg yolks of chickens. Poultry Sci 78: 1138-1150.

17) O'Connor RT, Heinzelman DC, Freeman AF, Pack FC. 1945. Spectrophotometric determination of alphaeleostearic acid in freshly extracted tung oil. Ind Eng Chem 17: 467-470.

18) Dyer JM, Tang F, Chapital DC, Lax AR, Shepherd HS, Shih DS, Pepperman AB. 1998. Differential extraction of eleostearic acid-rich lipid-protein complexes in tung seeds. J Am Oil Chem Soc 75: 1687-1690.

19) Folch J, Less M, Sloane-Stanley GM. 1957. A simple method for the isolation and purification of total lipids from animal tissues. J Biol Chem 226: 497-509.

20) Kaneda T, Nakajima A, Fujimoto K, Kobayashi T, Kiriyama S, Ebihara K, Innami T, Tsuji K, Tsuji E, Kinumaki T, Shimma H, Yoneyama S. 1980. Quantitative analysis of cholesterol in foods by gas-liquid chromatography. J Nutr Sci Vitaminol 26: 497-505.

21) Stanton C, Lawless F, Kjellmer G, Harrington D, Devery R, Connolly JF, Murphy J. 1997. Dietary influences on bovine milk cis-9, trans-11-conjugated linoleic acid content. J Food Sci 62: 1083-1086.

22) Dhar P, Bhattacharyya DK. 1998. Nutritional characteristics of oil containing conjugated octadecatrienoic fatty acid. Ann Nutr Metab 42: 290-296.

23) Sakono M, Miyanaga F, Kawahara S, Yamauchi K, Fukuda N, Watanabe K, Iwata T, Sugano M. 1999. Dietary conjugated linoleic acid reciprocally modifies ketogenesis and lipid secretion by the rat liver. Lipids 34: 997-1000.

24) Belury MA, Moya-Camarena SY, Liu K-L, Vanden Heuvel JP. 1997. Dietary conjugated linoleic acid induces peroxisome-specific enzyme accumulation and ornithine decarboxylase activity in mouse liver. $J$ Nutr Biochem 8: 579-584.

25) Tanaka K. 1974. Metabolism of long-chain fatty acids in the rumen. Jpn J Zootech Sci 45: 307-318. 